IRA-International Journal of Education and Multidisciplinary Studies ISSN 2455-2526; Vol.07, Issue 03 (2017)

Pg. no. 215-227

Institute of Research Advances

http://research-advances.org/index.php/RAJMSS

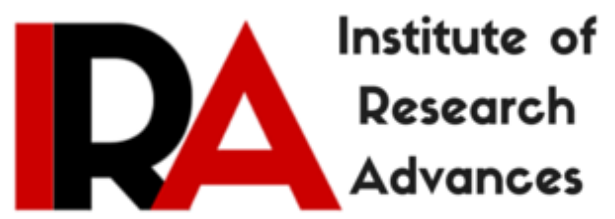

\title{
Extent of Involvement of Parents in the Identification of Children with Special Needs in Kenya
}

\author{
Josphat Shaduma Bonjo ${ }^{1}$, Kochung J. Edward ${ }^{1} \&$ Nyangara Karen ${ }^{2}$ \\ ${ }^{1}$ Department of Special Education and Rehabilitation School of Education, Maseno \\ University, P.O Box Private Bag, Maseno, Kenya. \\ ${ }^{2}$ Department of Educational Communication, Curriculum Development and Technology \\ School of Education Maseno University, P.O Box Private Bag, Maseno, Kenya.
}

Type of Review: Peer Reviewed.

DOI: http://dx.doi.org/10.21013/jems.v7.n3.p6

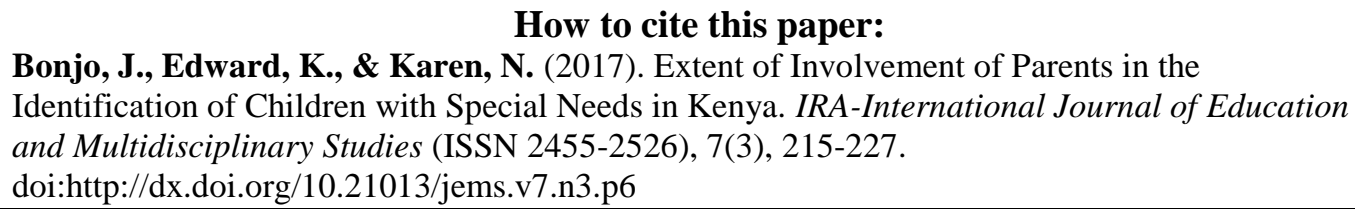

How to cite this paper:

Bonjo, J., Edward, K., \& Karen, N. (2017). Extent of Involvement of Parents in the Identification of Children with Special Needs in Kenya. IRA-International Journal of Education and Multidisciplinary Studies (ISSN 2455-2526), 7(3), 215-227. doi:http://dx.doi.org/10.21013/jems.v7.n3.p6

(C) Institute of Research Advances

$(\mathrm{cc})$ EY-NC

This work is licensed under a Creative Commons Attribution-Non Commercial 4.0 International License subject to proper citation to the publication source of the work.

Disclaimer: The scholarly papers as reviewed and published by the Institute of Research Advances (IRA) are the views and opinions of their respective authors and are not the views or opinions of the IRA. The IRA disclaims of any harm or loss caused due to the published content to any party. 


\begin{abstract}
The assessment of children with special needs is an important component of SNE. The process of educational assessment involves identification of children with special needs and disabilities, administration of tests and intervention. The Educational Assessment and Resource centers (EARCs) in Kenya are mandated to provide assessment services. The principles of assessment require the involvement of parents in the assessment process. Preliminary survey on 120 parents from 10 counties whose children had special needs reveals that only 51(43\%) parents were involved in the assessment process. The roles of parents include provision of background information; instruction of children during the administration of the tests and training children after assessment. What is unknown is the extent of parental involvement in the assessment process at the EARCs in Kenya. The purpose of this study was to establish the extent of parental involvement in the identification of children with special needs in Kenya. The objectives of the study were to; examine the involvement of parents in the identification of children with special needs. The study employed descriptive survey research design. The target population was 47 assessment teachers, 94 parents of children assessed and 47 parents of children to be assessed from 47 centers in 47 counties in Kenya. Saturated sampling technique was used to select assessment teachers. Purposive sampling was used to select parents of the already assessed children and 41 parents of those to be assessed. Questionnaires, interview guides, observation schedules and document analysis guides were used for data collection. Face and content validity of the instruments were ascertained by experts from the department of Special Needs Education Maseno University. Reliability of the instruments was determined through a pilot study on $10 \%$ of the population using test-retest. The acceptable reliability was set at $r=0.70$.Quantitative data was analyzed using frequency counts, percentages and mean scores. Qualitative data was organized and reported in an on-going process as themes and sub-themes. The study found out that there was a minimal involvement of parents in the assessment process at the centers in Kenya $(M=2.18)$. The study concluded that assessors with training specifically in assessment were positive in involving parents in the assessment process at the EARCs compared to those who had qualifications in SNE without a specific training in assessment. The study recommends that a certificate or diploma course tailored to train assessors in assessment procedures, assessment techniques, guidance and counseling, referral and placement procedures be introduced at a relevant institution to train only assessors. It is also recommended that a policy on assessment procedures to harmonize assessment services in Kenya be enacted by the government. The research findings may help to improve parental involvement in the assessment process at the EARCs in Kenya.
\end{abstract}

Key words: identification, assessment, parental involvement Background to the Study

Identification refers to being alert to early warning signs of difficulties or problems present in a child. These difficulties may be special needs or disabilities. Parental involvement in the identification process is now legal in various countries like Britain, America, Canada, Egan, (2005). Farrell, (2009) has argued that parents involved in the identification process by providing information on the etiology of the condition of the child, being aware of the services available and referring the child to proper services. The professionals at his level may partner with parents in providing information on the community resources through the media.

Professionals may also support parents by organizing group activities. Lewis (1981), and Mangal, (2011) argue that parents are in a position to value information in the identification stage of the special education assessment. Lewis also points out that parents are aware of the developmental status of their children and, if provided with the information about the early signs of handicapping conditions may be able to identify possible problems in the preschool years. Even with school age children, if parents are given information about the characteristics of various handicaps they can be of immeasurable assistance in identifying learners with disabilities. 
In Britain the law requires that children are screened at birth and a report made available to parents. In case of the presence of a disability the parents are counseled and information of the future services is provided. In America the public law 92-175 recognize parents as persons with information that may help in the identification of children with special needs. Parents by nature are close to the child from birth and may provide useful information which assessors may use to detect the cause of the difficult or problem. Parental experiences and perspectives serve as a resource in the partnership with assessors in the assessment process. Carpenter, (2000) has described the relationship between parents and assessors as a stepping stone for the purpose of identification. Carpenter further points out that it is the cooperation of assessors and parents that sets the way forward for intervention. In Uganda parents are contacted in hospitals as soon a child is born, Oketch, (2002). The social workers and medical personnel counsel the parents and information for future services like the educational assessment and early training are provided. In Kenya the parents are contacted through the churches, schools and hospitals for the purpose of assessment. Some parents from their own experiences and print and electronic media may seek the services of assessment by themselves. Parents are a resource in the identification process and without their input the assessment process is incomplete.

Tobin (1983) studied the involvement of parents in the training of children with visual impairments in a center in England. He encouraged parents to train their children who had low vision at home. On assessment after some time the children whose parents were involved in the training had improved in their visual tasks. Tobin encouraged parents to come to the center instead of home training. The extent to which the parents were involved in the training at home was minimal. It was more of clinical training. Identification of the difficulties of the children was left for the researcher. Parents should have been asked to identify the problems of the children after interacting with them at home. At the moment there is no study showing the extent of parental their children before the assessment process commences. This study aims at finding the extent to which parents are involved in the identification of their children for the purpose of assessment at the EARCs in Kenya.

\section{Statement of the Problem}

It is the policy of the government that parents must be partners in the assessment process. The tests manuals direct parents to be involved in the assessment process by supporting the assessors at every stage of assessment. A preliminary survey showed that out of 120 parents only 51 (43\%) was involved to some extent in the assessment process at the centers. There is minimal involvement of parents at the identification, administration of the test, referral and placement levels. The interaction of parents and assessors during the assessment process pose some challenges which seems to contribute to parental involvement in the assessment process at the EARCs in Kenya. It is the contribution of parents at every stage that provides assessors with the basic information which forms the basis of intervention programmes. Without the partnership of parents the assessors may not identify the children's special needs due to communication difficulties and psychosocial problems. All the intervention activities in homes cannot be implemented without the partnership of parents. It is unknown to what extent parents are involved in the assessment process at the EARCs in Kenya.

\section{Purpose of the Study}

The purpose of the study was to determine the extent to which parents are involved in the identification process of children with special needs.

\section{Objective}

The specific objective to this study was to determine the extent to which parents are involved in the identification process of children with special needs. 


\section{Research Methodology}

This research was conducted through descriptive research design. This research design was used to investigate how assessment personnel interact with the parents during the assessment process. The descriptive research design had advantages for the researcher because a range of procedures were used such s questionnaires, interviews and observations to gather relevant information for triangulation. Besides this, information was gathered in the natural environments in homes where parents lived with their children ( Mugenda \& Mugenda, 2003). The study was conducted in Kenya in 47 EARCs in 47 counties. The centers were purposively selected because the assessment services were offered there.

\subsection{Study Population}

The target population comprised of 3,480 parents whose children had been assessed at the centers, 47 parents whose children had been booked for an assessment, and 47 assessment teachers in 47 EARCs. The assessment teachers were supposed to have worked in the centers for at least a year. in this study Simple random sampling technique was used to select 47 assessment centers from the 47 counties. Simple sampling technique selects a sample without bias from the target population. In this study the technique was used so as to ensure that all the centers were equally represented from the whole country. Purposive sampling was used to select 2 parents from the 47 centers (94parents) whose children had already been assessed for an interview. $30 \%$ of this population (28 parents) targeted for this study. 47 parents whose children were booked for assessment (one parent from each center) of which $30 \%$ of the population (14 parents) were targeted for the purpose of observing and video recording during the administration of the tests. An established long serving center with personnel and equipment from each county was selected purposively for this study.

\section{Table 1.3: Sample Frame}

\begin{tabular}{lcl}
\hline Respondents & Population $(\mathrm{N})$ & \multicolumn{2}{c}{ Sample size } \\
& $\mathrm{F}$ & $\mathrm{f}(\%)$ \\
\hline Parents with assessed children & 94 & $80(90)$ \\
Parents with children booked for assessment & 47 & $38(90)$ \\
Assessment teachers & 47 & $38(90)$ \\
\hline
\end{tabular}

In this research, questionnaires, interview guides and observation schedules were used as instruments.

In this study test items were based on the objectives. Content validity was used to establish validity of the instruments. Content validity is the degree to which test items in test represent in type and proportion content designed to measure. Content validity is also determined by an objective comparison of the test items with the coverage of the topics in the course to ensure that the items represent the topics in terms of type and proportion Drost, (2011). In this study the researcher designed questionnaires, interview schedule and observations schedule in relation to the objectives. Content validity was ensured by obtaining subjective judgment by the experts of the concerned field as observed by Bryman and Bell, (2003); Sekaran, (2003).Expert judgment of the instruments was undertaken by the experts to establish the validity of th questionnaires, interview guide documents analysis guide and observation guides The experts evaluated the relevance of each item in the instrument in line with the objective of this study.

A test in the form of questionnaire was administered to the 4 assessors, an interview administered to 10 parents of children already assessed and an observation in an assessment center of 4 children being assessed. Later the process of retesting was repeated to the subjects after two weeks. The reliability coefficient of assessors questionnaires was calculated using Pearson product moment correlation coefficient and it was 0.74 at P-value of 0.5 was judged as reliable. Reliability for the questionnaire to the assessors was 0.858. Reliability for the parent's interviews whose children had been assessed was 
established through triangulation. Information gathered from the two pilot interviews seemed similar and therefore the instrument was considered reliable. Some corrections were made on the instruments before being administered to the main population. The population used in the pilot study was not used in the main study.

This study was investigating the involvement of parents in the assessment process at the EARC in Kenya. The questionnaire for assessment teachers were categorized into six themes thus, involvement of parents in identification, involvement parents in the administration of the tests, involvement of parents in referral and placement, involvement parents in intervention activities and difficulties encountered by parents and assessor sin the assessment process. The questionnaires sought the opinion of the parents in the involvement of the parents in the whole assessment process using items from the objectives (strongly agree, agree, undecided, Disagree, Strongly disagree).The observation schedule focused on activities derived from the behavior of the assessor, the child and the parent during the whole process of assessment at the center. This included how the parent was welcomed at the center, how the rapport is established between the parents the child and the assessor, the behavior of the assessor towards the child and the parent, the sitting position of the parent, the child and the assessor and how the assessor involves the parent in the test administration activities. The process was videotaped and analyzed in order to find out the frequency of parental involvement in the assessment process. The activities were measured passively (Very frequently, Frequently, Sometimes, hardly, and Not At All.). Quantitative data was analyzed using frequency counts, percentages, means, $t$ test, chi-square, factor analysis and multiple regressions. The alpha level of significance was set at .05 .

\section{Results and Discussion}

The purpose of this study was to find out the extent of parental involvement in the assessment process of children with special needs at the Educational Assessment and Resource Centers in Kenya. It was an assumption that the parents identify some special needs or disabilities and may refer the children to the hospital or assessment centers. The results are presented as per the objectives which include; extent to which parents are involved in the identification of children with special needs; the extent of parental involvement at the test administration level; Extent of parental involvement at the referral and placement levels and the challenges the assessors and parents encounter in the assessment process.

\subsubsection{Extent to Which Parents are Involved in Identification of Children with Special Needs}

To establish the extent of parental involvement, assessors were asked to share their views on the extent to which parents were involved in the identification. This involved various factors of parental involvement in assessment process. The results are presented as shown in table 2.

Table 2.4 Extent of Parental Involvement in Identification of Children with Special Needs.

\begin{tabular}{llllll}
\hline Statements & $\begin{array}{l}\text { larger } \\
\text { extent } \\
\mathbf{f}(\%)\end{array}$ & $\begin{array}{l}\text { large } \\
\text { extent } \\
\mathbf{f}(\%)\end{array}$ & $\begin{array}{l}\text { small } \\
\text { extent } \\
\mathbf{f}(\%)\end{array}$ & $\begin{array}{l}\text { smaller } \\
\text { extent } \\
\mathbf{f}(\%)\end{array}$ & $\begin{array}{l}\text { not at all } \\
\mathbf{f}(\%)\end{array}$ \\
\hline $\begin{array}{l}\text { Parents should be involved in the identification } \\
\text { process. }\end{array}$ & $4(8.5)$ & $5(10.6)$ & $9(19.1)$ & $11(23.4)$ & $18(38.3)$ \\
$\begin{array}{l}\text { Parents should be present during the administration } \\
\text { of the test. }\end{array}$ & $5(10.6)$ & $5(10.6)$ & $6(12.8)$ & $11(23.4)$ & $20(42.6)$ \\
$\begin{array}{l}\text { Parents should help with the instruction of their } \\
\text { children during the administration of the test. }\end{array}$ & $4(8.5)$ & $5(10.6)$ & $7(14.9)$ & $11(23.4)$ & $20(42.6)$ \\
$\begin{array}{l}\text { Parents should discuss with the assessors the } \\
\text { assessment results }\end{array}$ & $1(2.1)$ & $5(10.6)$ & $9(19.1)$ & $14(29.8)$ & $18(38.3)$ \\
$\begin{array}{l}\text { Parents should be guided to train their children at } \\
\text { home. }\end{array}$ & $4(8.5)$ & $5(10.6)$ & $12(25.5)$ & $16(34.0)$ & $10(21.3)$ \\
\hline
\end{tabular}




\begin{tabular}{lccccc}
\hline $\begin{array}{l}\text { Parents and other members of the family should be } \\
\text { involved in the intervention programmers }\end{array}$ & $5(10.6)$ & $6(12.8)$ & $7(14.9)$ & $11(23.4)$ & $18(38.3)$ \\
$\begin{array}{l}\text { Parents should be consulted before referral and } \\
\text { placement }\end{array}$ & $3(6.4)$ & $8(17.0)$ & $6(12.8)$ & $9(19.1)$ & $21(44.7)$ \\
$\begin{array}{l}\text { Parents should be guided and counseled at the } \\
\text { centers only }\end{array}$ & $5(10.6)$ & $7(14.9)$ & $7(14.9)$ & $12(25.5)$ & $16(34.0)$ \\
$\begin{array}{l}\text { Parents should be trained at the assessment centers } \\
\text { to support their children at home }\end{array}$ & $1(2.1)$ & $2(4.3)$ & $3(6.4)$ & $12(25.5)$ & $29(61.7)$ \\
$\begin{array}{l}\text { Parents experience communication difficulties } \\
\text { with assessors }\end{array}$ & $3(6.4)$ & $7(14.9)$ & $7(14.9)$ & $9(19.1)$ & $21(44.7)$ \\
$\begin{array}{l}\text { Parents experience difficulties understanding the } \\
\text { results of the assessment tests }\end{array}$ & $2(4.3)$ & $4(8.5)$ & $8(17.0)$ & $8(17.0)$ & $25(53.2)$ \\
\hline
\end{tabular}

The results in table 2 indicate that majority of the assessors, 18(38.3\%) were against parental involvement in the identification process. This is unfortunate on the part of the professionals because already parents had noticed a problem with the child before presenting the child in the center which implied that the parents had identified part of the problem before confirmation at the canters. They should instead be encouraged as Jones et al (2006) points out that parents are a resource in the assessment process since they know their child best from the birth history. The same trend was also reflected in their suggestion against parental presence during the administration of the test. 20(42.6\%). Some 20(42.6\%) further felt that parents should not at all help with the instruction of their children during the administration of the test. The study results also revealed that assessors were against discussion of the assessment results with the parents as reported by $18(38.3 \%)$ of them. However, they had neutral views on parental guidance to train their children at home as reported by the majority. Another aspect that was against assessors expectation was the involvement of the parents and other family members in the intervention programs as reported by $18(38.3 \%)$. The rest of the aspects of parental involvement were seriously sidelined by the assessors. These included consulting parents before referral and placement, which was the majority, 18(38.3\%) were against, guiding and counseling parents at the centers only, 16(34.0\%), training parents at the assessment centers to support their children, 21(67.1\%) and finally communication and understanding difficulties, 21(44.7\%) and 25(53.2\%) respectively.

Table 35 Mean Views of the Involvement of Parents in the Assessment Process by the Assessors.

\begin{tabular}{lll}
\hline Statement & Mean & Std \\
\hline Parents should be involved in the identification process & 2.28 & 1.32 \\
Parents should be present during the administration of the test. & 2.23 & 1.39 \\
Parents should be present during the administration of the test. & 2.19 & 1.33 \\
Parents should discuss with the assessors the assessment results & 2.09 & 1.10 \\
Parents should be guided to train their children at home. & 2.51 & 1.20 \\
Parents and other members of the family should be involved in the intervention & & \\
programmers & 2.34 & 1.39 \\
Parents should be consulted before referral and placement & 2.21 & 1.35 \\
Parents should be guided and counseled at the centers only & 2.43 & 1.38 \\
Parents should be trained at the assessment centers to support their children at & 1.60 & 0.95 \\
home & 2.19 & 1.33 \\
Parents experience communication difficulties with assessors & 1.94 & 1.20 \\
Parents experience difficulties understanding the results of the assessment tests & \\
\hline
\end{tabular}


The results in table 3 indicate that the assessors views on parental involvement in the identification process was minimal and to a small extent $(\mathrm{M}=2.28, \mathrm{SD}=1.31)$. The extent to which parents were present during the administration of the test is low $(\mathrm{M}=2.23, \mathrm{SD}=1.39)$. The extent to which parents should be present during the administration of the test was also low $(\mathrm{M}=2.19, \mathrm{SD}=1.33)$, discussion of the assessment results with the assessors, $(\mathrm{M}=2.09, \mathrm{SD}=1.1)$ guiding parents to train their children at home $(\mathrm{M}=2.51, \mathrm{SD}=1.19)$ involvement of the parents and other family members in the intervention programs $(\mathrm{M}=2.34, \mathrm{SD}=1.39)$, consulting parents before referral and placement $(\mathrm{M}=2.21, \mathrm{SD}=1.35)$, guiding and counseling parents at the centers $(\mathrm{M}=2.43, \mathrm{SD}=1.38)$, training parents at the assessment centers to support their children $(\mathrm{M}=1.6, \mathrm{SD}=0.95)$. Communication and understanding difficulties by parents $(\mathrm{M}=2.19, \mathrm{SD}=1.32)$ and $(\mathrm{M}=1.94, \mathrm{SD}=1.21)$ respectively.

It is the policy of the government that parents must be part and Parcel of the assessment process, Republic of Kenya, (2009). The policy aims to improve the growth of SNE programmes and services by placing emphasis on assessment and early intervention This view were emphasized by the Warnock report (1978) IN Britain which saw the parent as a central player in assessment process, observed that if parents are not seen as partners in the assessment process of their children their report would be frustrated. The results further concurred with O'Connor (2005) who noted that parents should not be seen as clients but as partners in the services to their children with special needs. The professionals "knew it all" and the parents believed it. 0'cconnor (2005) argues that role of professional's perceived status of dependency and passivity, thereby reducing parent's capacity to engage in equal relationship with professionals. To support the need for parental involvement, Jonnes and Drummond (2006) pointed out that a power sharing relationship between parents and educators can encourage greater empowerment and equality in decision making leading to establishment of agreed parameters of mutual accountability and responsibility. The manual for the administration of the tests (see appendix 6) directs assessors to work with parents in the administration of the test. Some activities in language and social emotional sub-tests for children below five years need the presence of a parent in order to administer for the purpose of consultation and giving the child confidence to accomplish the tasks on the test. The absence of a parent in the assessment clinic or minimal involvement in the administration, as noted in table 5.9, is detrimental to the assessment process in Kenya.

An interview was carried out in order to determine parental involvement in the identification of children with special needs. In order to achieve this, parents were asked their views about the assessment process in relation to the objectives of this study. Their questions sought views on how they identified the disabilities of their children, whether the assessors informed them of the importance of background information and its confidentiality, how the assessors prepared them before the administration of the tests to their children, whether the assessors sought their views before referral and placement and the difficulties they encountered in the whole assessment process.

\section{Interviewer: "How did you know that your child had a disability?"}

The majority of the parent $73.1 \%$ s said they noticed abnormal movements, growth behavior, abnormal growth of limbs, and delayed developmental milestones which prompted them to seek advice from friends and family members. Some of them said they were informed from the hospital that the children had disabilities. Some 8 parents (18\%) said they noticed the difficulties but because of cultural beliefs they waited for a miracle before accepting that their children had difficulties or special needs... This was common among pastoral communities who believed that it was a curse to have a child who was handicapped in the family. One mother retorted that she gave birth to twins and she had to hurriedly abandon the husband because in her ethnic community first born twins are a curse and have to be killed. It is even worse if one or all of them have a disability. Twins who are first born in a family in this community are treated as handicapped persons.

Parent: "I noticed that my child walked with difficulties". 
From this feedback, it is clear that parents could identify the physical disabilities of their children. However, there was no any other form of disability that parents could identify. Most of them were only able to identify according to what they could see, such as disabilities that were visible on their children's body. Concerning other forms of disabilities, parents had views as one of them noted,

\section{"I dint know until the doctors informed me about it"}

These are disabilities that may not be identified as early as possible. They include deafness, visual impairments, learning difficulties, specific learning difficulties, and mental challenges.

This concurs with the findings of Paul (1981), Mangal, (2011), Mittler and Mittler, (2000). Bonjo, (2002) that parents identify their children's problems but may not understand their management until the professionals' partner with them.

It was rare for parents to notice gifted and talented children. This kind of disability was reported not to be noticed by one of the parents after failing to realize the nature of her child's difficulty.

\section{"I was not aware until teachers told me that my child was gifted and talented".}

The interview revealed that parents had some knowledge about the disabilities of their children and that they had initiated a process of i9ntevention with relatives, friends, and professionals. They had to some extent been involved in the identification process but the degree of involvement was still to be realized. Some parents $(7.5 \%)$ only learnt of the problems with their children from school $14 \%$. One parent noted

\section{"I did not know what the problem my child had until I was called to school and learnt that he was performing poorly in class. I took him to the assessment center and was told he has hearing problems"}

This parent could not relate the poor performance and the problem the child experienced in school. She could not identify the disability until the child was assessed in the assessment center. This implies the EARCs play an important role in the identification of the disabilities of the children. Although some parents discovered the difficulties with their children but the majority needed confirmation from the centers. These were children who had learning difficulties, specific learning difficulties and behavioral difficulties. The analysis shows that to some extent some parents were involved in the identification of their children with special needs except for those disabilities that need a compressive assessment to detect. This is in line with Mittler, 2005 who in a research through an interview confirmed that parents may identify the difficulties to some extent and only those that are visible.

It is in my view that the luck of training for the assessors is likely to have contributed to assessors unwilling to involve parents in the administration of the tests. Jones et al (2006) has noted that parents must be communicated to before and after testing so that they rare ware of the process otherwise the tests might cause more anxiety to the parents.

\section{Conclusions and Recommendations}

\section{Conclusions}

This study was to find out how parents are involved in this identification of their children who have special needs for the purpose of assessment. It focused on how parents at any stage of their development identify special needs for the purpose of referral for assessment.

From the interview with parents, the views of assessors and the observations made in the assessment center parents were involved to a minimal extent in the identification of their children's difficulties. Only 
a few of them identified the needs as early as possible while the majorities were informed either by the school or hospitals that their children had special needs. It was the luck of knowledge about various categories of children with special needs which contributed to the parent's poor identification of the needs of the children. Besides this the degree of education and literacy also made a difference in the knowledge and interest of identifying the children at this level for the purpose of assessment. Tobin (2000) cites a study with parents whose children had low vision and were asked to train their children's vision at home. Tobin found out that those parents who were literate were willing to participate in the training at home than those who had informal education. Literacy plays a role in the acceptance of working with professionals. Mittler and Mittler, (2000) also concurs with Tobin's study.

In regard to observations at the centers the majority of the parents explained the conditions of the children and it was evident that they had noticed the children had special needs. However parents when prompted to suggest the cause of the special needs cultural beliefs dominated the identification of the needs.

The involvement of parents in the identification of children with special needs is very minimal in assessment centers in Kenya. The research returned a minimal involvement of parents (This is also confirmed by Njeri and wambugu (2015) in a recent research in two special schools and two regular schools where they found out that those parents who were not provided with basic information before the admission of their children. Assessors do not encourage parents to identify difficulties in their children and particularly those with hidden disabilities. The involvement of parents in the identification process is a pre-requisite for later involvement in the whole assessment process.

\section{Recommendations}

The study recommends the following which arose from the results:

(i) A government policy on the development EARCs and their management in reference to devolved county units, the training of assessors, and the role of the stakeholders would be appropriate.

\section{References}

American Psychological Association, Practice and science Directorates (2000). Report on Task Force on Test

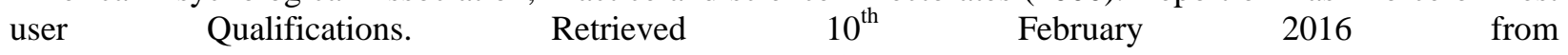
htt://www.apa.org/science/progras/testing/qualificatioos.pdf

Bailey, B. D., \&Wolery, M. (2002).Teaching Infants and Pre-schoolchildren with Handicaps. Journal of Early Intervention. 25, 58-75.

Beveridge, S. (1993).Special Education needs. Handbook of gifted and talented education( $3^{\text {rd }}$ ed.). Tip press (Padston ltd) Padston Cornwa

Best, W. J. \& Kahn, V. J.(2006). Research in Education (10 ${ }^{\text {th }}$ Ed): New Delhi: Prentice-Hall.

Blacher, J. (2002). The mystery of family research: Parents magically change from invisible to prominent. Exceptional parent, 32, 46-48.

Bloom, B. S. (1964).Stability and change in human in human characteristics. New York: Wiley.

Bonjo, J. S. (2002). The cooperation between parents and assessment teachers at the EARCs in Kenya.A case study of the EARCs in Kenya. A thesis submitted for the requirements of a M.PHIL(SNE). Oslo University. Norway.

Bryman, A., \& Bell, E. (2003).Business research methods.UK:Oxford University Press.

Bronfenbrenner, U. (2006). The ecology of human development.International encyclopedia of education, 3 (2). Oxford: Elsevier. 
Carpenter, M. (2000). Sustaining the family.Meeting the Needs of Families of Children with Disabilities.British Journal of Special Education, 27, 135-144.

Chine, T., \& Fredrickson, N. (2002).Special Education Needs, inclusion and diversity.Open University press. USA.

Dale, N.M.(1996). Working with families of children with special Needs: Partnership and practice. New York.

Davis, G.A.,\&Rimm, S. B. (2004). Education of the gifted and talented (5 ${ }^{\text {th }}$ ed.).San Francisco: Allyn and Bacon.

Domscheit-Chalef, C. (1998). Sharing assessment data Effectively. In Volta review Vol 1-98 (5).

Drew, J. J.,\& Hardman, M. L. (2004). Mental retardation.A lifespan approach to people with intellectual disabilities $\left(8^{\text {th }}\right.$ ed.). Columbus, $\mathrm{OH}$ : Merrill.

Education for All.(2000). Assessment of progress Kenya Country Report. Draft report, August, 1999.Nairobi.

Egan, W. M., Clifford, J. D., \&Hardman, L. M. (2005).Human Exceptionality-school, Community, and Family ( $8^{\text {th }}$ ed.). Person Education, Inc. New York.

Ferrel, A. K. (1977). Working with parents in Foundations of Education for the blind and visually handicapped Children and youths. Theory and Practice edited by Geraldine T. Scholl. American Foundation for the BlindNew York.

Farrel, M. (2009).The special Education Handbook( $4^{\text {th }}$ ed.).David Fulton Publishers. United Kingdom.

Featherstone, H. (1980). A difference in the family. A diference in the family.New York, N. Y. Basic books In Foundations of Education for the Blind and Visually handicapped Children abdYouths. Theory and Practice edited by Geraldine Scholl 1986.

Fichtner, D. (1979).How to raise a blind child.A guide to those who work with pre schoolchildren.ChristoffelBlinden Mission- Bensien. Germany.

Fischer,S.(2012).Fathers are caregivers too. (Online) Available: http/www.fathersnetwork.org/572html

Frightener, L. W. (1994).Pre-school screening for development problems. Ottawa-Health Canada.

Gall, M. M. Gall, J.P. \&J. P. \& Borg, W. R .(2007). Educational research: An introduction (8 ${ }^{\text {th }}$ ed.). Boston. Pearso International.

Garner, P. (2009). Special Educational Needs.The key concepts.Routledgem (Tyailor and Francis Group).London and New York.

Gestwicki C. (2000) School, and Community Relations. A guide to working with families. $4^{\text {th }}$ ed.Delmar. New York.

Gronlund, N. E. (2000). How to write and use instructional objectives ( $6^{\text {th }}$ ed). Columbus. OH: Merril/ Prentice- Hall.

Guralnick, M. J. (2001).A framework for change in early childhood inclusion.Baltmore, MD: Paul H Brookes.

Hewad, L. W. (2009). Exceptional Children: An introduction to special Education (9 $9^{\text {th }}$ d.). Pearson Education, Inc. Pearson Prentice Hall.Ohio State University.

Heward W.L., Jill C. Dardig, Allison Rosett, (2005). Working with parents of handicapped children-Bell and hawellcompany-Columbia: London: Sydney.

Hewad, W. L. (2009). Exceptional Children (9 ${ }^{\text {th }}$ ed.).London.David Fulton Publishers.

Hornby, G.,\&Richard,S.(2000). Meeting special needs in the mainstream schools: A practical Guide for teachers ( $2^{\text {nd }}$ ed.).

Hornyby, G. (2010). Inclusion Theory and Practice for students of special Schools. Burton Journal of Special Education in $21^{\text {st }}$ century pp 119-135 .Haunjacollege.NY.NOVA Science Publishers. 
Jackson, N.E. (2003).Young gifted children. In N. Colagnelo and G.A Davis (Eds)

Jefree O. M. D. (1987). Let me speak. Souvenir Press Ltd.

Jin, S.,\&Feldhusen, J.F. (2000). Parent identification of the talents of gifted students.Gift education Internatinal14, 230-236.

Kenya Institute of Special Education.(2005).A guide to training parents at the EARC. Nairobi, Kenya.

Kenya National Bureau of statistics (2010). Kenya population and Housing Census 2009. Nairobi. Government Printer.

Kochung, E. (2000). Support Based Screening Procedure for Preschool in Kenya. Joensuun: University of Joensuun Publishing Press.

Kothari, C. R. (2006). Research methodology: Methods and techniques (2 ${ }^{\text {nd }}$ ed.). New Delhi: New age International publishers. New Delhi.

Krejcie, R. V.,\& Morgan, D. W. (1970). Determining Sample Size for Research Activities.Educational and Psychological Measurement 30, 607-610.

Kristensen, K., (1984). Educational Assessment and Resource Services in Kenya. A paper presented to assessment teachers seminar. Nairobi.

Kroth, R. L.,\& Edge, D. (2007). Communicating with parents and families of exceptional Children( $4^{\text {th }}$ ed.). Denver: Love.

Kvale, S. (1996).To validate is to question: Issues of validity in qualitative research. Stockholm.

Lake, J. F.,\& Billingsley, B. S. (2000). An analysis of factors that contribute to the parent school conflict in special education. Journal of Remedial and special education 21, 240-251.

Lambie, R. (2000b). Working with families of at risk and special needs students: A system change model.Journal of Focus on exceptional children, 32, 1-23.

Lewis, B. L.,\&McLaughlin, A. J. (1981). Assessing Special Students. Charles E. Merrill Publishing Company. London.

Lim, S. Y. (2008). Parent involvement in the education.In G. Olsen \& M. L. Fuller (Eds.) Home school relations.Working successfully with parents and Families pp-122_150). Boston: Allyn and Bacon.

Littlewood, R. (2001). "A case definition and culture: Are people all the same?"Comment.British Journal of Psychiatry, 179, 460.

Malone, M.D. (2007). Mothers Perception Regarding the Social Competence of Pre-school Children with Mental Retardation.Journal of Developmental and Physical Disabilities, 19 (4), 365-383.

Mangal, S. K. (2011).Educating Exceptional children: An introduction to special education.PhH learningPrivate limited. New Delhi.

Mann, T.L.,\& Powers, S.(1997).Screening and Assessment for Head start programmes Servicing Infants and toddlers. A paper presented in the $24^{\text {th }}$ workshop at the National head start Association Training conference Boston: National Center for infants, Toddlers, \& Families

McMillan, J. H., \& Schumacher, S. (2001). Research in education: A conceptual introduction (5 $5^{\text {th }}$ ed.). David Fulton Publishers. London.

Merrel, K.W. (2000). Behavioral, social and emotional assessment of children and adolescence ( $2^{\text {nd }}$ ed.).Mhwah, N. J.Lawrence Erbaum.

Ministry of Education - The Basic Education Bill 2012 in Daily Nation $4^{\text {th }}$ July 2012.

Ministry of Education Annual Report. (2012).Assessment Services in Kenya. Government Printer.Nairobi.

Ministry of Education (MoE).(2005). Manual for EARC services in Kenya. 
Mitchel, D. (2008). What really works in special education-Using evidence- based teaching strategies. Routledge.Taylor and Francis Group. London.

Mitchel, D.(2010).Parental involvement. College of Education, University of Cantebury, Ministry of Education. UK.

Mittler, P. (2000). Working towards inclusive education: Social contexts. David Fulton Publishers: London.

Mittler, P. J., \&Mittler, P. A. (2000).Training for inclusion.Canadian exceptionality press. Canada.

Mori, (1984).Quoted by Ferrel in foundations of education for blind and visually handicapped Theory and practice by Geraldine Scholl. American foundation for the blind. New York.

Moris, J.K.,\& Blatt. (1986). Special Education Research and Trends. New York: Prgmon

Mugenda, O. M., \& Mugenda, A. G. (2003).Research methods: Quantitative \& Qualitative Approaches. Nairobi: Africa Centre for Technology Studies (ACTS).

Mussen, P. H. (Ed.). Carmichaels manual of child psychology ( $3^{\text {rd }}$ ed., vol.1). New York: Woley.

Nitko, A. J. (2001). Educational assessment of students ( $3^{\text {rd }}$ Ed.). Columbus, OH: MerrilPrentice- Hall

Oconnoru.McConkey R, Hartop, B (.2005).in European Journalo f Special Education. Vol.20, No 3, August 2005,pp251.

Odeny, M. A. (2005). Educational Assessment and Resource Services. Nairobi: Kenya Institute of Special Needs Education Publishing Press.

Odom, S. L., \& Bailey, D. B. (2001).Inclusive pre school programs. Classroom ecology and child outcomes. In M. J. Guranlick (Ed), Early childhood inclusion: Focus on change pp 253-276, Baltimore, MD: Paul H Brooks.

Organization for Economic Cooperation and Development (OECD).(2008). Review of national policies for Education of South Africa.OECD publishers.

Oketch, J.B. (2002). Educational Assessment and Resource Centres. Kampala: Uganda National Institute of Special Education Publishing Press.

Orodho, A. J. (2005). Techniques of writing Research Proposals \& Reports in Education and Social Sciences. $\left(2^{\text {nd }}\right.$ ed.). Kaneza Enterprises. Nairobi.

Paul, L. G. (1986). Multicultural considerations in Foundations of Education for blind and visually handicapped children and youth. Theory and practice edited by Geraldine Scholl, American Foundation.

Pierangelo, R. and Giulian, G. A. (2006).In production to assessment and overview.In NASSET. Retrieved from https://www nasset.org/fileadmin/user uploaded?assessment/intro to assessment\&overview.pdf. on February $11^{\text {th }}$ 20116at 8012 pm.

Quenomoen, R.,\& Thurlow, M. (2003). NCEO policy directions. Including alternate assessment results in accountability decisions (online).

Available:

http://education.umn.education/nucea/onlinepubs/policy13.htmretrieved July $10^{\text {th }} 2012$.

Ramey, C. T., \& Ramey, S. L. (1999).Right from birth. New York: Goddard Press.

Republic of Kenya. (2001). The children's Act, 2001. Nairobi: Government printer.

Republic of Kenya.(2003). Persons with disability Act, 2003. Nairobi: Government Printer.

Republic of Kenya.(2003). Report of the task force on special needs Education Appraisal exercise. Nairobi: Government printer.

Republic of Kenya. (2005). The sessional paper No 1 of 2005. Nairobi: Government Printer.

Republic of Kenya.(2008). MOE draft on Special Needs Education Policy.Nairobi: Government printer. 
Wambugu N. B. and Njeri K. J. (2015).Psycho_educational assessment in Kenya. A special needs education perspective. In Prime social science. ISSN:2315-5051

Republic of Kenya.(2009). National Special Education Policy framework. Nairobi: Government Printers.

Republic of Kenya.(1999). Report of Inquiry into the Education System of Kenya. Nairobi: Government printer.

Reuters, T. (2012).Assessment for effective Intervention.Journal of the Hamill Institute on disabilities.USA.

Ridley, D. (2009). The Literature review.A step by step guide for students. SAGE Publishers Ltd.

Rye, H. (2000). Teacher parent interaction and collaboration.International Institute Division. University of Oslo- Norway.

Santarrelli, G., Koegel, R. L., Casa, J. M., \&Koegel, L. K. (2001). Culturally diverse families participating in behavior therapy family parent education programs for children with developmental disabilities. Journal of positive behavior intervention, 3, 120-123.

Schwartz, I. S., \& Rodriguez, P. B. (2001). A few issues to consider: The who, what,and where of family support. Journal of early intervention, 24, 19-21.

Sheldon, S. B. (2002).Parents social networks and beliefs as proctors of parent involvement.Elementary school journal 102,(4), 301-316.

Slee, R. (2006).Critical analyses of inclusive Education Policy; An International Survey. International Journal of inclusive Education, 10,(2,3), 105-7.

Taylor, L. R. (2008). Assessment of Exceptional Students. Educational and Psychological Procedures ( $8^{\text {th }}$ ed.).Florida Atlantic University. Prentice-Hall, Inc.

Taylor, L. R. (1989). Assessment of Exceptional Students: Educational and Psychological Procedures. New Jersey: Prentice Hall.

Taylor, S.V. (2000). Multicultural is who we are. Literature as a reflection of ourselves. Journal of Teaching Exceptional children, 33, (3), 24-29.

The Education Act (1981) A.M.S.O. UK

The Warnock report (1978).H.M.S.O. United Kingdom.

Thomas, G., \& Loxley, A. (2007).Deconstructing Special Education and Constructing Inclusion (2 ${ }^{\text {nd }}$ ed.).Buckingham; Open University Press.

Turnbull, A., Strickland, B.R., Brandles, J. (1978). Developing and implementing IEPs. Columbus, Ohio chase E. Merril'

Tyunan, W. D., \&Wornian, K. (2002).Parent management training: Efficacy, Effectiveness to barriers implementation. Report on emotional and behavioral disorders in youth, 2, 57-58, 71-72.

Venn, J. J. (2000). Assessing students with special needs ( $2^{\text {nd }}$ ed.). Columbus. OH: Merril/Prentice Hall.

Warren, D.H. (1984). Blindness and early childhood development revised ( $2^{\text {nd }}$ ed.). New York

Washington, Alexander Graham BCSS Association.

White, B. L. (1975). TheFirst Three Years of Life. Eaglewood Cliffs, NJ. Prentice Hall.

Yssldyke, J.E. (1986). The use of Assessment Information to make decisions about Students. In Morris, J.\& Platt, B. (eds).Special Education Research and Trends. New York: Pergmon Press, page 8-28.

Njeri K. J. and Wmmbugu N. B. (2015). Psycho Educational Assessment in Kenya. A special needs education perspective. In Prime social science. ISSN: 2315-5051

Republic of Kenya.(2009). National Special Education Policy framework. Nairobi: Government Printers. 